\title{
ARCHITECTURES OF DEMOCRACY: HOUSING MOVEMENTS AND PROGRESSIVE ARCHITECTS IN SÃO PAULO (1970-1990)1
}

Arquiteturas da democracia: movimentos de moradia e arquitetos progressistas em Sáo Paulo (1970-1990)

Arquitectura de la democracia: movimientos de vivienda y arquitectos progresistas en São Paulo (1970-1990)

JOSÉ HENRIQUE BORTOLUCI ${ }^{\mathrm{I}}$

http://dx.doi.org/10.1590/\$2178-14942018000300004

\footnotetext{
${ }^{1}$ Esta pesquisa foi financiada por bolsa Capes/Fulbright e pelo Departamento de Sociologia da Universidade de Michigan. I Fundação Getulio Vargas (FGV), Rio de Janeiro - RJ, Brasil.

Doutor em Sociologia pela Universidade de Michigan e professor da Fundação Getulio Vargas (FSJ-FGV). (jose.bortoluci@fgv.br)

Artigo recebido em 9 de Março de 2018 e aceito para publicação em 10 de Setembro de 2018.
} 


\begin{abstract}
From the late 1970s until the early 1990s, the issue of the right to housing in São Paulo's peripheral neighborhoods was pursued side by side with a questioning of the political character of design and construction techniques and an attempt to reframe the construction site as a space of cooperation and political education. This article addresses how this articulation between architects and urban social movements led to an innovation of organizational practices within those movements, transformations in the field of architecture, and the local emergence of the idea of the "right to architecture."
\end{abstract}

\title{
KeYwordS: Housing moverrents; Architecture; Democracy, Political repertoire; São Paula, Periphery.
}

\section{RESUMO}

Entre o final dos anos 1970 e o início dos 1990, a temática do direito à moradia nos bairros periféricos de São Paulo avançou em paralelo a um questionamento do caráter político do projeto arquitetônico e da construção, e a uma tentativa de reconfigurar o canteiro como um espaço de cooperação e educação política. Este artigo investiga como uma articulação entre arquitetos e movimentos sociais urbanos levou a inovações nas práticas organizacionais desses movimentos, a transformações no campo de arquitetura e à emergência local da ideia de um "direito à arquitetura".

PAlAVRAS-CHAVE: Movimentos demoradia; Arquitetura; democrada; Repertório política, São Paula, Periferia.

\section{RESUMEN}

Entre el final de los años 1970 y el inicio de los años 1990, la temática del derecho a la vivienda en los barrios periféricos de São Paulo avanzó en paralelo a un cuestionamiento del carácter político del proyecto arquitectónico y de la construcción, y a un intento de reconfigurar el sitio de construcción como un espacio de cooperación y educación política. Este artículo investiga cómo una articulación entre arquitectos y movimientos sociales urbanos llevó a innovaciones en las prácticas organizativas de estos movimientos, a transformaciones en el campo de la arquitectura y al surgimiento de la idea de un "derecho a la arquitectura".

Palabras ClaVE: Movimientos por lavivienda; Arquitectura; Democrada; Repertorio política, São Paula, Periferia. 


\section{INTRODUCTION}

F rom the mid-1960s until the 1980s, critical intellectuals in Latin America discovered "the subaltern". In fact, they discovered several different forms of subaltern knowledge, subjugated practices, and popular repertoires of organization that shook traditional understandings about the historical formation of the lower classes, their characteristic forms of agency, and their potential role in social struggles. During this period, several radical experiments in critical pedagogy (Freire, 2014), action research (Fals-Borda, 1991), theater (Boal, 2000), and other cultural realms attempted to promote a dialogue with the experiences and knowledge of subaltern social groups and, to a certain extent, to break the barriers that separated popular cultural manifestations and elitist institutions, such as theater, cinema, and the university. Although the main intellectual strands of thought that oriented these experiments with a new political epistemology were developed in the 1960s, authoritarian regimes in the region retarded their full development in different national contexts for at least a decade (Aparicio and Blaser, 2008).

An analogous process happened to architecture in São Paulo from the late 1970s until the early 1990s. An emergent program for low-income housing among progressive architects in association with social movements and neighborhood associations challenged the previous forms of engagement between urban professionals and low-income city residents, who had historically been responsible for the production of the built spaces that they inhabited in the city. In this period, the issue of the right to housing in São Paulo's peripheral neighborhoods was pursued side by side with a questioning of the political character of construction techniques and an attempt to reframe the construction site as a space of cooperation and political education. In this article, I address two central questions: What materials and construction techniques were more conducive to the materialization of these emergent political ideas and practices? How did these new materials and techniques affect those repertoires?

Methodologically, I do not intend to provide a detailed history of any specific housing project, although most of my examples will come from two empirical cases: Copromo ${ }^{1}$ and União da Juta ${ }^{2}$. Both complexes were built in a regime that combined self-build cooperative construction, self-management, and collaborative design under the responsibility of Usina, one of the technical offices in São Paulo that specialized in this type of project. My data was gathered through life-history interviews with residents, housing activists, and architects who worked in these two and other comparable housing projects from the same period (see appendix 1), as well as archival research and several visits to several housing complexes. 
In the following sections, I briefly reconstruct the main elements of the political discourses and practices that emerged within the Brazilian left during the late 1970s through the early 1990s and the core values and repertoire of the housing movement in São Paulo in that period. Then, I show how architects attempted to develop new materials and techniques of design and construction that would allow for the material articulation of the main elements of that political repertoire. Finally, I analyze some of the negotiations and tensions between the aspirations of the housing activists and architects.

\section{EMERGENT SOCIAL ACTORS AND THE POLITICAL REPERTOIRE OF PARTICIPATION}

he years between 1978 and 1988 were a period of intense political and intellectual
creativity. This creativity is expressed above all in the emergence of social movements at the peripheries of the largest cities as well as in rural areas, the strengthening of labor unions in the late 1970s and 1980s, the articulation of a progressive politics within the Catholic Church under the growing influence of liberation theology, the flourishing of counter-hegemonic artistic and student movements, and the dissemination of new research agendas among progressive intellectuals.

New movements mobilized to tackle issues associated with the worsening of life conditions in São Paulo's peripheries. Of particular importance in São Paulo were the emergence of a movement against scarcity ("movimento contra a carestia"), movements of unemployed workers, clubs of mothers that demanded the construction of day-care centers, and movements for improvement of public transportation. Other movements demanded the creation of a public health system or promoted mobilizations around issues of race, gender, or sexual oppression. And, of course, several neighborhoods created associations to push for the legalization of their land titles, for the improvement of urban infrastructure, and — even more important for my purposes here — for the construction of new housing units (Gohn, 1991).

Many of these movements were able to breach, if somewhat imperfectly, the traditional divide between the factory and the neighborhood - a persistent split in the previous decades in São Paulo, with rare exceptions (Fontes, 2008; Kowarick, 2000: 74). On many occasions, this peak of activism favored the creation of multiclassist alliances (Kowarick, 1987), particularly when specific areas of local or thematic activism connected with the national struggle against the military regime - a process that lasted from the early 1980s until the approval of the new constitution in 1988. 
This experience of activism led to the dissemination of new collective experiences that deeply impacted the lives of the individuals and communities that took part in them, representing a new dynamics of collective subjectification (Rancière, 1991). This new political repertoire incorporated a new grammar of rights - and of citizenship as the right to have rights (Arendt, 1973; Gohn, 1991; Holston, 2009: 14). Finally, these movements developed or incorporated a gamut of new contentious performances that manifested those new values: land occupations, neighborhood meetings, religious ceremonies with political purposes, elaboration of draft articles to the new constitution, and collective housing construction, among others.

\section{HOUSING MOVEMENTS AND THE RIGHT TO HOUSING}

$\mathrm{H}$ ousing movements expanded dramatically at São Paulo's peripheries from the late 1970s until the early 1990s. Actually, what emerged was an extensive articulation of movements that addressed issues of the right to land and to housing, legalization of irregular occupations, slum urbanization, democratization of construction processes, and the management of housing programs - as well as the more traditional neighborhood associations (Gohn, 1991). This large "social movement industry" (McCarthy and Zald, 1977) profited from (and also helped to induce) the opening of political opportunities in the Brazilian political system throughout the 1980s, as well as from the election of state and local government officials who were more attuned to those new forms of organization and accepted the opening of new political channels between the administration and the organized sectors of civil society — such as governor Franco Montoro (1983-1987) and São Paulo's mayor Luiza Erundina (1989-1992).

These new movements represented a development of the traditional forms of popular occupation of land and production of the city, but they also innovated in their claims, forms of organization, and frames. Some of the movements that emerged in this context organized occupations of public or private properties in São Paulo, mostly in peripheral neighborhoods. These occupations were part of a larger strategy that involved attraction of the state's and the media's attention, the demand for the construction of housing units in the occupied properties, and a plan for the consolidation and expansion of those movements, since these occupations attracted homeless families (or families who lived in precarious housing units) that could potentially become part of those organizations.

One of the most important occupations took place in 1981 at Fazenda Itupu, a 0.63 square kilometer public empty lot in the southern region of São Paulo, which was carried out by around 3,000 families. On the same day, those families also informally divided that land 
into around 2,000 housing lots - a practice that would be repeated in several occupations after that, but which did not prevent their eviction by a police force of 3,000 officers (Sardi, 1987). This occupation received wide attention in the national media, and it became a formative event to several organizations throughout the metropolis (Gohn, 1991: 73).

Reginaldo Oliveira de Almeida (Didi) ${ }^{3}$, one of the main leaders of a series of occupations and self-build cooperatives in Osasco, a municipality in the western region of the São Paulo metropolis, recalled the first phases of the struggle for the establishment of Copromo, one of the earliest and most influential experiences of the housing movement struggle in the region:

Low wages, very high rents in the 1980s... and there was this world of land here in front of us that was said to be owned by Cohab... Then we went on and occupied that land. We called it "invasion" at the time. We went there and occupied it all. We set up headquarters there, and Cohab came with trucks and knocked it down. It was a hell of a bush this terrain, but we resisted several demolitions of our headquarters. Then, after the fourth time they knocked it down, I think, it was the carnival of 1986, then we decided to occupy it permanently... Father Ferraz, who has passed away, this priest was the one who guided us the most, who helped and gave us courage... About four thousand families occupied it... We were organizing the community here, and we met Adão Pedreiro, who was killed in a movement activity in São Paulo. Then we agreed that when we occupied here, they would occupy another piece of land in São Paulo. And then the police would come, and we were determined to die, because we had nowhere else to go. Either we stayed on the land or we died in police hands.

Didi's description touches on the main conditions, performances, and discursive frames that were part of the repertoire of housing activism in the 1980s and early 1990s in São Paulo. First, he mentions the housing crisis that manifested in a growing housing deficit and a continuous rise of rent across São Paulo. This crisis was one of the consequences of the continuous growth of the metropolis at a time of severe economic crisis and the failure of official programs to meet this growing demand, especially after the closing of BNH in 1986. Moreover, Didi describes a common dynamic of struggle: the occupation of public land and the organization of families to exert pressure on the state for the construction of houses. This organization usually led to the creation of ties across the metropolis, with the coordinated action of organizations that engaged in simultaneous land occupations — signaling a routine of exchange and learning, particularly among leaders of each local organization.

Furthermore, progressive members of the Catholic Church played a central role in helping the movement to organize and to foster a general atmosphere of hope at the grassroots level. Activists in different regions of the metropolis emphasize the role played by different bishops 
and priests in organizing the movement. Several of these religious men and women also acted as negotiators and brokers between the movements and the state.

Didi also mentions the symbolic struggle that took place at the linguistic level: the term invasão (invasion) would soon be replaced by the term ocupação (occupation) in the vocabulary of housing activists and their political allies to designate the initial phase of the struggle, during which families squatted on the land that they claimed. Invasão denotes a violent and illegitimate act and highlights the breaching of ownership rights, while ocupação connotes a more legitimate act of claim making — for the right to housing, in this case. By framing their actions as an occupation, housing movement leaders attempted to stress their demand for participation in the emergent civil society and to put forth the claim that the right to housing and to land should be seen as at least as important as the right to property. Finally, Didi pointed to the violent and very frequent clashes with the state and the police, which could, in some cases, lead to the death of activists, as in the case of Adão Pedreiro.

Housing movements were frequently organized in different hierarchical levels, from local "origin groups" up to national organizations. The origin groups were responsible for organization, political education, and communication with local families. Beyond that, a regional sphere of the movement concatenated and coordinated the activities of origin groups and cooperatives in a certain region of the metropolis. Finally, each of these regional organizations was commonly associated with a larger movement (for example, the União dos Movimentos de Moradia - UMM, or the Union of Housing Movements). These larger organizations were part of a constellation of groups with different levels of articulation that were active in the field of housing, right to land, and the right to the city broadly defined such as the Landless Workers Movement (MST), the National Movement for Urban Reform (MNRU), the movements of tenement residents, and several slum dwellers' organizations. The three levels of the movement acted in coordination during land occupations and in negotiations with the municipal or state governments. After a certain piece of land was assigned for the collective construction of social housing, an association was formed, comprising members from different origin groups in a certain region. Families in all origin groups accumulated points for participating in movement activities, such as protests, occupations, and construction routines. These points would define when a family would be allocated to one of the self-build associations. These associations were usually responsible for hiring a technical office ("assessoria técnica") that would help them define a project and coordinate the construction work. 


\section{HOUSING LABORATORIES AND THE CONNECTION BETWEEN ARCHITECTS AND HOUSING MOVEMENTS}

his intensification of activism and organization at São Paulo's peripheries did not go
unnoticed by progressive architects, who had been experimenting with new forms of engagement with peripheral populations since the mid-1970s. In 1975, the São Paulo Architects Union (SASP) promoted a first organized attempt to work with a community on the outskirts of the city, in the working-class neighborhood of São Miguel Paulista. The leadership of the union invited Joan Villà, a Catalan architect who lived in São Paulo, to take part in the project. Villà had studied architecture at FAU-Mackenzie and, between the late 1960s and early 1970s, lived in Europe to escape persecution from the military regime, given that he had been a militant in the Brazilian Communist Party. In Spain and Italy, he became acquainted with the experiences of cooperatives of architects, many of which had anarchist inclinations. Those cooperatives were influenced by autonomist ideas of workers' self-management, which were an important part of the constellation of the left in Europe at the time, after "autonomism" became a philosophy and practice of activism (Alcoff and Alcoff, 2015; Eley, 2002). Villà had the chance to get to know the work of architects in low-income communities in those countries. Along with Jorge Alfredo Carone and Alfredo Paesani, he formed the Cooperative of São Paulo Architects Union. Villà described some of the challenges they experienced in the attempt to approach those communities in the first phase of that experience:

I had a meeting with all the priests of the diocese.... What I was going to propose, and I was hoping they'd accept, is that at Sunday masses for a month they would announce that we would go there.... Here were the architects and the people who went to mass; [the priest] had already announced that we would go that Sunday, and there were many people... architects met people and organized the work; then in the evenings at the headquarters of the union, which was on Avanhandava Street, I read everything and distributed the work. We got all sorts of demands, from people who had a house about to fall owing to infiltration or because a small stream invaded their plot.

However, that experience, one of the first institutionalized attempts to overcome the huge geographical, cultural, and political distance between the field of architecture and the struggles for housing at the peripheries, had very limited success. Villà comments on the reasons for this initial failure:

Fundamentally, it failed because it was a very naïve thing... None of the architects had ever set foot in a place that was more than three or four kilometers away from Praça da Sé; the majority lived in neighborhoods such as Pinheiros, Perdizes etc., etc. That is, they had no knowledge of 
the periphery, not even through cinema... Initially, it meant entering a completely unknown universe, and the other thing that I also saw very clearly was an absolute and complete unpreparedness to design with limited resources.

This "naiveté" that Villà describes shows the lingering effects of the spatial and social division between architects (even progressive ones) and the population of São Paulo's peripheries. A second reason for the relative failure of the experience, according to Villà, was the fact that the cooperative was working with individual families and not with associations and movements, as would become the common practice a few years later.

However, this pilot experience helped to shape other relevant movements of renovation of architectural practice in the period. Some of the architects involved in the experience of the cooperative, especially Jorge Caron and Villà, founded the architecture program at the Faculty of Fine Arts (Faculdade Belas Artes) in 1979 — the third higher-education institution to offer training in architecture in the city. At Belas Artes, Villà coordinated the housing laboratory starting in 1982. This lab was the first experience of its kind in São Paulo. The lab was intended to renovate the practices of design and construction within a context of lack of resources and in direct contact with the neighborhood associations and the housing movements that had started to grow in the period. The faculty at the laboratory also included Nabil Bonduki, Antônio Carlos Sant'Anna, Olair de Camilo, Ives de Freitas, and other younger architects who would later work in technical offices that provided assistance for low-income communities. The lab would be closed in 1985 by the school administration after a faculty strike that led to the firing of Villà and other lecturers. At the time of its demise, the laboratory was involved in housing projects in two different peripheral neighborhoods in the southern region of São Paulo: Grajaú and Recanto da Alegria.

Vitor Lotufo, who worked at Recanto da Alegria, expresses this change of political perspective among progressive architects and the divergence from the previous dominant generation:

The major concern that existed with respect to public housing [in the 1960s] was industrialization. I think the mentality at the time was that a house should be like a car. The more it was produced, the more industrialized, the cheaper it would be, and more people would have access to housing, right? And I think it's a poor vision of housing. For us, the dominant motive was to build with the people.

Similar principles were also being disseminated at the same time in other spheres of the field of architecture in the city. At Mackenzie, for example, students throughout the 1980s had growing contact with experiences of democratic planning, and some were deeply influenced by lecturers who had worked with self-build cooperatives. One office that would be very active 
in this area, Ação Direta (Direct Action - AD), was formed by Mackenzie graduates. Joel Felipe, one of AD's members, describes the general feeling that he shared with some of his colleagues: these young professionals were not to work only for the reproduction of a "designer's architecture" ("arquitetura de grife"), but they should also be involved in community organizationesd very frequent laiments. Then, dists and their political alliesn of a "e shared with some of his coleagues that e deeply infl.

Popular building practices and materials motivated many of these attempts to develop cheaper construction techniques, such as soil-cement (similar to rammed earth) and later experimentation with on-site prefabricated concrete blocks, which were further developed at Unicamp, where Villà started to work in 1985 together with architects and engineers (such as João Marcos Lopes and Yopanan Rebello) who would later open technical offices dedicated to work with social movements and communities.

Influenced by this experience, the young engineer Guilherme Coelho visited Uruguay and recorded on video the experience of these cooperatives. Coelho would drive around the peripheries of the city, showing this video to neighborhood associations and new housing social movements. This video and the discussions it fostered influenced the self-managed housing project in Vila Nova Cachoeirinha, in which Coelho was involved, and many other projects on the outskirts of São Paulo throughout the 1980s, when the screening of his video became a typical "business card" in exchanges between progressive young architects and housing movements (Baravelli, 2006). The Uruguayan experience influenced local discussions about self-management, the development of cheaper and accessible construction techniques, and the practice of association between architects and local communities in São Paulo. During the 1980s and early 1990s, several housing movement leaders as well as architects involved in this new modality of design and construction visited Uruguayan cooperatives to learn from their experiences with autoconstruction and self-management.

One of the techniques that Villà and his colleagues developed at Belas Artes and later at Unicamp was also inspired by what they observed at a construction site in Uruguay and, according to Villà, in the architecture of Eladio Dieste, the Uruguayan architect who was known for a peculiar use of catenary arches and brick. The technique of ceramic blocks, developed by Villà and his associates, addressed the specific needs of construction in a situation in which the workforce does not have deep familiarity with construction techniques, especially with the use of concrete. Ceramic blocks were produced horizontally by pouring cement to connect ceramic bricks; those blocks would then be lifted — often manually, if they were small and light enough — and used in the construction of roofs and walls. Several housing 
movements in the state of São Paulo heard of the "Unicamp model" and adapted it to their local needs (Gohn, 1991). Earlier in their work at Recanto da Alegria, Villà, João Marcos de Almeida Lopes, Roberto Pompéia, Vitor Lotufo, Nabil Bonduki, and Antonio Carlos Santanna attempted to adapt a traditional technique of construction with rammed earth (soil mixed with cement) that was cheap but that also took a significant physical toll on the members of the community building those houses, who had to perform the tough work of ramming the mixture to produce the soil-cement.

This new form of collaboration between architects and housing movements gained traction in the late 1980s with the creation of new offices (such as Usina, Fase, and Ação Direta). Architecture journals such as Arquitetura \& Urbanismo and Projeto slowly recognized the work of those communities and architects. Also, a new progressive leadership was elected at São Paulo Architects Union in 1987, many of whom had previous experience working with housing movements.

This impact on the field of architecture accompanied a change in the practices of design toward an inclusion of the workers and residents in the practices of planning and management of the housing projects. This new politics encompassed an emergent "regime of legibility" that contrasted with the previous ideology of design that previously dominated the field of architecture in São Paulo. Wagner Germano, from Usina, describes this process:

But the fact is that you have a construction site with people who have no experience in construction; a very large part of those people did not have specific training, did not have proper skills to work in construction... So, the drawings had to be done in a way that a person with no training in construction would be able to read.

Nevertheless, the use of easy-to-learn techniques and, in some cases, low-tech materials was also accompanied by the preoccupation to lower the prices of construction, diminish the physical toll, and speed up the construction process. Many of the technical offices suggested the use of fabricated components, particularly the ones that demanded higher technical skills such as stairs.

\section{CONSTRUCTION AS AN ARENA OF ARTICULATION}

T he combination of participatory design, self-management, and cooperative construction became widespread in São Paulo's peripheries from the mid-1980s through the early 1990s. Like many other social movements during the previous thirty years in different Latin American contexts (Alcoff and Alcoff, 2015; Aparicio and Blaser, 2008), those construction si- 
tes became spaces for the "performance of community" by means of the manipulation of signs (drawings, regulations, plans, spreadsheets) and materials (blocks, concrete, tools).

Isabel, a resident and activist who participated in the construction of União da Juta, succinctly describes the collective construction process:

We came [on weekends], depending on the task force... We had task forces according to what we had to do, like masonry, hydraulics, electric work... The hardest part of the construction was the foundations because it's hard work, and no one sees with naked eyes because it is all under the ground. You dug the ditches, poured concrete, did everything, but nothing came out of it. So, folks would get discouraged and say: "oh God, we will never end this," but that is how it's done, in task forces, with people who opened the trenches, while others moved out the earth, and others made hardware frames.

Wilton, a resident at Copromo and an experienced construction professional who worked in several different self-build cooperatives, points out that a lot of the excitement with the construction process stemmed from the residents' perception that their work would be directly converted into something of their own:

[The self-build cooperative] is great. It's great because ... you work with people, with these humble people, and you can feel that person's dedication. They come over on the weekend; they know what they are doing. If they are digging or if they are carrying a bucket, if she's leveling the land, whatever they are doing, they say, "Oh well, this will be my house," even though they don't know exactly where their apartment will be yet.

Several of my interviewees, both architects and activists, asserted, however, that the benefits of collectively designing, managing, and building something that was to be their own and the moments of exchange and learning that marked this process were balanced by a series of challenges. These hurdles stemmed from the arduous nature of the work itself, from the lack of continuous assistance and the frequent conflicts with state agents, and the occasional disputes between the movement's leadership and architects working on certain projects.

Underneath all these limits and frictions, a controversy about the essence of this method of construction and organization came up in a few interviews. In the statements of architects and activists, the model of the self-build cooperative is sometimes described as a utopia and sometimes as a "necessary evil". Wagner Germano, an architect at Usina who worked with several communities summarizes the later position:

So why the self-build cooperative [mutirão]? It's not an option.... It's the lack of an option.... We always said: it would be nice if one day we could have ... the community manage the resources. So it would get the funding. Then it would hire the technical staff to make the project, and then 
it would manage the construction work, hire workers, hire a contractor or a few little construction companies, maybe some cooperative of construction workers. Then people wouldn't have to spend weekends doing heavy work... So this intense contact of the families participating in the collective construction process, meeting all weekends to work on the construction site... We thought it was an opportunity for us to discuss some other things.

More frequently, both frames ("utopia" and "necessary evil") were used interchangeably by the same actor. For example, Isabel emphasizes the physical burden imposed by that kind of work - one that was conducted mostly by women, many of whom were elderly, with no previous experience in construction - , but she also highlights how that method of management, construction, and organization generated a sense of community and empowerment:

When we construct as a self-build cooperative, it's good because nobody knows where your unit will be; you know it's here, but you do not talk like this: "I will work because this is my place." No one knows. We knew we each had a unit, but we didn't know exactly where, so no one could be careless with the others because everybody wanted to finish their houses... It is very tiring; those who don't like to fight, to organize, they give up!

Beyond the strenuous nature of the work, Isabel's testimony highlights one of the conflicts that took place in several different projects: the difficulty of maintaining solidarity and assuring the continuous participation of all the future resident families. In order to guarantee their participation, the movement leadership implemented several strategies, from informal follow-up and political education to a system through which the leadership of each organization attributed points to participation in cooperative activities, from construction to attendance at meetings, town halls, and rallies.

Furthermore, the dominant narratives of housing activists emphasize the impact of this method of construction and management for the constitution of strong social ties in those communities that would remain active to a large extent for years after the conclusion of construction. Although it is certainly true that collaborative construction impacts certain aspects of occupation - for example, there is ample evidence that the initial residents tended to stay in those houses years after its initial occupation, at a much higher rate than in other forms of social housing - there are also several testimonies that challenge the extent of this impact. All my interviewees emphasized the strong connection among the future residents and the concern with creating positive collective dynamics after occupation. But some mention that those strong ties were not preserved after the conclusion of building. In other words, the alternative dynamics of construction seemed to have a mild impact on the dynamics of habitation. This impact also seemed to vary depending on the social and urban context of each of these 
housing complexes. For example, when asked about the relationships within the community after occupation, Wilton, from Copromo, says:

I'Il tell you something, that's what the problem is. Because we were closer friends when we were building than after living here. Because people now go in and out of their homes and say "hi, good afternoon, good morning, good night", and this is it.

In contrast, Didi, one of the main leaders of Copromo during construction and occupation, has a different perspective:

Because [the cooperative work] lowers the costs of living for those who are making it, everyone can make it; then one values more what he did. Look, we are here in this neighborhood, which is called "Terra é Nossa"; 4 here and even in Copromo, there are no fights, no deaths, because we've lived together one, two years, building together, doing something collective, so there is mutual respect between people.

Many activists, as well as architects and scholars, argued that the methods of work and the organization of the construction sites did not solve the problem of overexploitation of the workforce (Carvalho, 2004; Oliveira, 2006). Some of the associations required that families put in up to eighty weekly hours of work for construction and other activities (Gohn, 1991: 119), tasks that could be painstakingly exhausting to many of those worker-residents.

Nevertheless, in contrast to the traditional process of self-construction organized at the family level, this collective articulation represented a significant political opportunity for the dissemination of a new language and new values of citizenship among those families. Many of the activists and architects involved also considered the pedagogical construction site as a space where at least a few of the future residents could develop technical skills that could lead to new professional opportunities in the future - which seems to have been the case for at least a small fraction of them, according to some of my interviewees.

\section{THE “RIGHT TO ARCHITECTURE”}

T his program for the built environment also corresponded to an attempt to forge a new economy of dignity in which the "right to architecture" was to be incorporated as a horizon. A major process of political conscientization and symbolic resistance in this new economy consisted in reimagining what a house for a poor family should be and to attack the widespread conception that those families would not be able to plan and manage the construction of their housing. 
According to my interviewees, as well as several documents on the politics of low-income housing in the period, this conception of the poor family as a passive recipient of a house was hegemonic among architects and engineers employed at housing agencies, such as Cohab and CDHU. Many of the activists and architects involved in cooperatives enjoy telling stories about the clash between their expectations and the beliefs and habits of those state agents. As Isabel, for example, recalls:

We were organized and wanted decent housing, so we didn't accept CDHU's project... I remember to this day when our technical assistants brought the first project that was different from CDHU's, and we liked it.... [CDHU's staff would say:] "The problem is that you came up with a very large project. This is not for the poor; this is a project for rich people." We replied, "We'll show that we can make it. We fought for it; we fought for our rights. It is not because we are poor that we have no right to have a decent and good house."

Wilton also recalls one of these encounters with a CDHU engineer:

Do you know what the guy told me? He said: "How do we, poor people like us, want to live in a middle-class apartment?" ... I turned to him and said, "So we have to live in matchbox? So we have no right to live in a nice apartment?"

Every activist and architect I interviewed shared similar stories of clashes between " mutirantes" and state officials and employees. The strategy of confronting these firmly held notions about how the poor should live attests that, at least in the case of the most active families, the new repertoire deeply affected their notions of self-worth, dignity, and rights.

Activists and architects point out that many of the future residents themselves also shared those conceptions about what constitutes appropriate housing for lower-class families. The work of convincing public officials needed to be carried out in tandem with the process of political education of the future residents in order to reconstruct the traditional view of what "low-income housing" should look and feel like, how it should be built, and what spaces it should occupy in the city. In this precarious situation, social movement leaders and architects working with those movements did not initially find fertile terrain for a discussion about design, aesthetics, and environmental and material quality. These topics usually emerged during the process of organization and after long discussions and town hall meetings of activist families and architects.

Reginaldo Ronconi, an architect who had worked with cooperatives since his days as a student at Belas Artes, shares one memory: 
At Recanto da Alegria, I was discussing a window with Clotilde. We would expand her house, build a new room. She had no money to buy a window, but I was there discussing with her where we were going to place the window and that we would deal with the issue of money later. We had to discuss where the opening would be - we would have to put the lintel, the architrave.... She turns to me and says: "I don't need this window here; this is only my room." "But how come you don't need a window, Clotilde?" "Well, I don't need it. Does a jaguar have a window where it lives?"

In this exchange between Clotilde and Reginaldo, the political pedagogy involved in the collaborative work of construction and design in this program becomes clear. The process of designing and installing a window becomes a gateway for a discussion of rights, privileges, and dignity. Discussing, designing, managing the funds, and later building a window worked as a process of reimagining the human condition and the economy of dignity to which (and of which) that individual was subject.

The concept of "the right to architecture" would be incorporated as part of the housing policies during Luiza Erundina's administration, when Ronconi, Bonduki, and other architects who had previously been involved with self-build cooperatives took the lead in providing resources and formulating the guidelines for social housing cooperatives (Bonduki, 2000).

\section{FINAL REMARKS}

elf-build cooperatives were not seen by most of the activists and professionals involved as
solutions to all urban problems in a context of poverty and deficient state planning. They were pragmatic solutions that called for the acceptance and transformation of traditional practices of self-construction, resignified by the collective organization of those families. They also involved a political and semiotic resignification of what housing for low-income families shouId "look like" and "feel like" and how it should be integrated into the city and in the context of the new formation of rights that was germinating in Brazil at the time. This resignification also involved the reconstruction of material practices of design and construction, providing a new source for the renovation of the field of architecture.

Housing complexes built by collectively managed self-build cooperatives in association with progressive architects were described by one key architect as "spaces of utopia" (Bonduki, 1986). It is important, nevertheless, to point out that this was a grounded utopianism (Aparicio and Blaser, 2008), or a pragmatic utopia that involved the congregation of existing practices and materials in spaces of limited prefiguration of new political practices - and, even more important for most of the residents involved, a pragmatic process for the acquisition of a house. 
It is not my purpose here to judge whether those architects and activists were able to fully accomplish this program - and the testimonies throughout this article show that this is an unsettled debate among them to our days. Nonetheless, even the most enthusiastic housing activists and architects were aware that the historical conjuncture imposed several limits to the advancement of that repertoire. Beyond the limited resources and the recurrent resistance of state agents, the political repertoire of cooperation and the constructive and organizational practices employed by the cooperatives had to live side by side with other practices and values, such as the valorization of property, occasional violence within some families, gender oppression, and disputes for leadership within and among different social movement organizations.

It is important to point out that housing activism has changed considerably in São Paulo since then. Successive municipal and state administrations during the 1990s disinvested from programs that funded self-build cooperatives; moreover, during Paulo Maluf's conservative administration (1993-1996), many social movement leaders were persecuted, and several housing projects remained unfinished until the early 2000s. Housing activism in São Paulo also suffered from the growing shortage of publicly owned land that could be the target of campaigns. Additionally, housing movements gradually diversified their geographic areas of action and their repertoires of contention, focusing more on squatting in underutilized or empty buildings in central regions.

More recently, a large federal program for low-income housing construction (Minha Casa Minha Vida, or "My House My Life") — implemented since the Workers' Party Luiz Inácio Lula da Silva's second term in the presidency (2007-2010) — has been steadily increasing the stock of low-income housing in most Brazilian cities, but in most cases under the same developmentalist and quantitative logic of the program funded by BNH during the military regime. This logic leaves aside crucial questions emphasized by housing activists and most progressive architects and urban planners: access to urban infrastructure, efficient transportation, and, last but not least, architectural and constructive quality. Only a very small percentage of the program's budget is committed to funding self-build cooperatives.

Despite the crisis that this program suffered in the last decades, it certainly left lessons for present day progressive architects and activists. It entailed a critique of the dominant practices that established the parameters of the design and construction of low-income housing in the previous decades. To use Walter Benjamin's description of Brecht's theater, activists and architects involved in the assemblage of this program proposed a "functional transformation" of the practices of architecture (Benjamin, 1998). Like Brecht's theater, this emergent program emphasized the moment of production as a crucial dimension of the politics of architecture. 
In this new theater, the audience was to be transformed into active collaborators, leading to a rethinking of the enduring practices of performance and potentially to the transformation of the of the spectators' political perspectives. In Walter Benjamin's words, Brecht's theater was a model for a progressive literature, because a writer's production should be a model:

It must be able to instruct other writers in their production and, secondly, it must be able to place an improved apparatus at their disposal. This apparatus will be the better, the more consumers it brings in contact with the production process - in short, the more readers or spectators it turns into collaborators. (1998: 98)

A very similar perspective on turning urban residents into collaborators in the process of designing and building low-income housing inspired the individuals and groups that advanced this emergent program in the peripheral neighborhoods of São Paulo.

\section{APPENDIX 1. INTERVIEWS}

Candido Malta (07/20/2011) - São Paulo

Caio Santo Amore de Carvalho (07/21/2011) - São Paulo

Giselda Visconti (08/28/2012) - São Paulo

Joan Villá (08/30/2012) - São Paulo

Roberto Pompeia (09/11/2012) - São Paulo

Yopanan Rebello (08/13/2012) - São Paulo

Sérgio Ferro (09/25/2012) - São Carlos

João Marcos de Almeida Lopes (10/02/2012) - São Carlos

Joel Felipe (10/03/2012) - Santo André

Geraldo Puntoni (10/10/2012) - São Paulo

Vitor Lotufo (10/18/2012) - São Paulo

Flávio Villaça (10/22/2012) - São Paulo

Hugo Segawa (10/29/2012) - São Paulo

Wilton da Costa Lima (10/31/2012) - Osasco

Arnaldo Martino (10/31/2012) - São Paulo

Ruth Verde Zein (11/09/2012) - São Paulo

Marina Heck (11/13/2012) - São Paulo 
Tiago Cavalcante Guerra (12/17/2012) - Guarulhos

Wagner Germano (08/29/2013) - São Paulo

Reginaldo Ronconi (08/29/2013) - São Paulo

Reginaldo Oliveira de Almeida (Didi) (09/10/2013) - Osasco

Isabel (09/11/2013) - São Paulo

Veronica (09/11/2013) - São Paulo

Pedro Jacobi (10/02/2013) - São Paulo

\section{(ENDNOTES)}

1 A housing complex with one thousand units divided into fifty-five-story buildings. The lot was initially occupied in 1987, and negotiation with public authorities lasted until 1991. Construction took place between 1992 and 1998, when the units were occupied. Construction was financed partly by CDHU, the state housing agency (680 units), and partly by the residents themselves (320 units).

2 A housing complex of 160 units, part of a larger complex where other associations also coordinated the initial occupation of the property as well as the planning and construction of the housing units. Fazenda da Juta, initially a private terrain, was occupied in the 1980s, and several organizations were formed to negotiate the purchase of the terrain. Associação de Construção União da Juta (Construction Association União da Juta) was part of the larger Housing Movement Association "Leste 1", which coordinated most of the struggle for housing in part of the eastern region of São Paulo. Negotiation with the state administration took place in 1992, and construction lasted from 1993 to 1998.

3 All remaining quotes in this article are from interviewees, unless specifically noted.

4 "Our Land", a neighborhood next to Copromo, also built after the occupation of an empty lot by the residents' cooperative in the 1980s.

\section{BIBLIOGRAPHY}

ALCOFF, Linda Martín; ALCOFF, José. Autonomism in Theory and Practice. Science \& Society, v. 79, n. 2, p. 221-242, 2015.

APARICIO, Juan Ricardo; BLASER, Mario. The "Lettered City" and the Insurrection of Subjugated Knowledges in Latin America. Anthropological Quarterly, v. 81, n. 1, p. 59-94, 2008.

BARAVELLI, José Eduardo. O cooperativismo uruguaio na habitação social de São Paulo. Master thesis (Universidade de São Paulo - USP), São Paulo, 2006.

BENJAMIN, Walter. The Author as Producer. In: . Understanding Brecht. New York: Verso, 1998, p. 85-103. 
BOAL, Augusto. Theater of the oppressed. Pluto Press, 2000.

BONDUKI, Nabil. Construindo territórios de utopia a luta pela gestão popular em projetos habitacionais. São Paulo, 1986. . Habitar São Paulo: reflexões sobre a gestão urbana. São Paulo: Estação Liberdade, 2000.

CARVALHO, Caio Santo Amore. A Lupa e o telescópio - o mutirão em foco. Master thesis (Universidade de São Paulo - USP), São Paulo, 2004.

ELEY, Geoff. Forging democracy: the History of the Left in Europe, 1850-2000. Oxford: Oxford University Press, 2002.

FALS-BORDA, Orlando. Action and Knowledge: breaking the monopoly with participatory action research. New York: Rowman \& Littlefield Publishers, 1991.

FONTES, Paulo. Um nordeste em São Paulo: trabalhadores migrantes em São Miguel Paulista (1945-66). Rio de Janeiro: FGV, 2008.

FREIRE, Paulo. Pedagogy of the Oppressed: 30th Anniversary Edition. Bloomsbury Publishing, 2014.

GOHN, Maria da Glória. Movimentos sociais e luta pela moradia. São Paulo: Loyola, 1991.

KOWARICK, Lúcio. Escritos urbanos. São Paulo: Editora 34, 2000. 1a ed.

- Movimentos Urbanos no Brasil Contemporâneo: uma análise da literatura. Revista Brasileira de Ciências Sociais, v.1, 1987.

MCCARTHY, John D.; MAYER, N. Zald. Resource Mobilization and Social Movements: A Partial Theory. American Journal of Sociology, v. 82, n. 6, p. 1212-1241, 1977.

OLIVEIRA, Francisco de. 0 vício da virtude: autoconstrução e acumulação capitalista no Brasil. Novos Estudos - CEBRAP (São Paulo), n. 74, p. 67-85, 2006.

RANCIÈRE, Jacques. The ignorant schoolmaster: five lessons in intellectual emancipation. Stanford University Press, 1991. 